\title{
visual neuroscience
}

\section{Vhs}

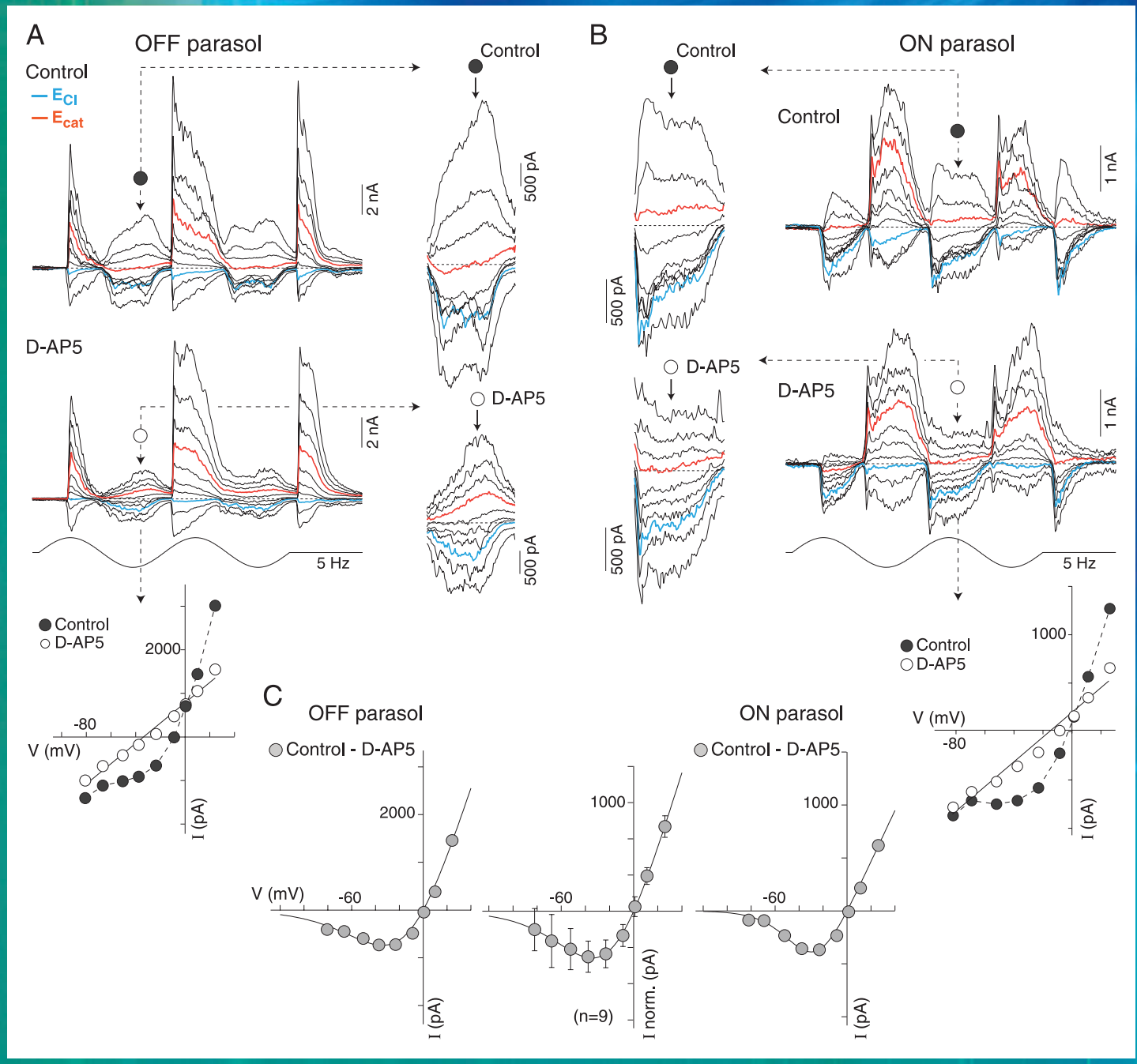

Volume: 31 


\section{visual neuroscience}

(ISSN 0952-5238)

EDITOR

BENJAMin E. REESE

University of California, Santa Barbara

\section{ASSOCIATE EDITORS}

Lynne Kiorpes, Center for Neural Science,

New York University, New York, NY 10003.

Peter D. Lukasiewicz, Department of Ophthalmology,

Washington University School of Medicine, Saint Louis, MO 63110.
Paul R. Martin, Sydney Eye Hospital \& Department of Ophthalmology University of Sydney, Sydney, NSW 2001 Australia.

David S. Williams, Jules Stein Eye Institute, UCLA School of Medicine, Los Angeles, CA 90095.

\section{EDITORIAL BOARD}

Alessandra Angelucci, University of Utah Jeannie Chen, University of Southern California

Shaun P. Collin, University of Western Australia

Jeffrey S. Diamond, National Institute for Neurological Disorders and Stroke

Ronald Douglas, City University, London

Robert M. Duvoisin, Oregon Health and Science University

John G. Flannery, University of California, Berkeley

Ulrike Grünert, University of Sydney, Australia

Silke Haverkamp, Max Planck Institute for Brain Research

Jonathan C. Horton, University of California, San Francisco

Gerald H. Jacobs, University of California, Santa Barbara

Maarten Kamermans, Netherlands Institute for Neuroscience

FORMER EDITOR (2002-2007)

LAURA J. FRISHMAN, University of Houston

FORMER EDITOR (1996-2001)

PETER D. SPEAR, University of Colorado at Boulder
Janis Lem, Tufts University

David W. Marshak, University of Texas at Houston

Maureen A. McCall, University of Louisville

Janine D. Mendola, McGill University

Maureen Neitz, University of Washington

Dario Ringach, University of California, Los Angeles

Marcello G. P. Rosa, Monash University

Evelyne Sernagor, Newcastle University

Robert G. Smith, University of Pennsylvania

Deborah Stenkamp, University of Idaho

Rowland Taylor, Oregon Health and Science University

Wallace B. Thoreson, University of Nebraska

Xian-Jie Yang, University of California, Los Angeles

FORMER EDITOR (1992-1996)

JAMES T. MCILWAIN, Brown University

FOUNDING EDITOR (1988-1991)

Katherine V. Fite, University of Massachusetts, Amherst

Visual Neuroscience (ISSN 0952-5238) publishes experimental and theoretical studies concerning the neural mechanisms of vision. Contributions may deal with molecular, cellular, and systems-level processes in both vertebrate and invertebrate species. Studies based exclusively on clinical, psychophysical, or behavioral data will be considered if they are related to neural mechanisms. Appropriate research areas include: photoreception and transduction, subcortical visual pathways, developmental processes, visually guided behavior, retinal structure and function, cortical mechanisms, oculomotor control, and substrates of perception.

Visual Neuroscience features full-length research papers, short communications, and review articles that critically examine topics related to the journal's principal focus.

Visual Neuroscience is indexed in Current Contents/Life Sciences; Science Citation Index; MEDLINE; Ocular Resources Review; Neuroscience Citation Index; and in the SCISEARCH and ISI/BIOMED databases.

Editorial Office: Benjamin E. Reese, Editor, Visual Neuroscience, University of California at Santa Barbara, Neuroscience Research Institute and Department of Psychology, Santa Barbara, CA 93106-5060, USA. Telephone/Fax: (805) 893-2091. E-mail: vns@lifesci.ucsb.edu

Publishing, Subscription and Advertising Offices: Cambridge University Press, 32 Avenue of the Americas, New York, NY 10013-2473, USA; and (outside the US and Canada) Cambridge University Press, The Edinburgh Building, Shaftesbury Road, Cambridge CB2 8RU, England.

Published online only in six parts in 2014: January, March, May, July, September, and November. Annual rates for institutions electronic only: US $\$ 1489.00$ in the US, Canada, and Mexico; UK £884.00 + VAT elsewhere. Individuals electronic only: US \$386.00 in the US, Canada, and Mexico; UK $£ 227.00+$ VAT elsewhere. Students electronic only: US \$143.00 in the US, Canada, and Mexico; UK £85.00 + VAT elsewhere.

Visual Neuroscience is part of the Cambridge Journals Online (CJO) service. Access to online tables of contents and article abstracts is available to all researchers at no additional cost. Access to full text articles online is currently included with the cost of electronic subscription. Subscription must be activated: for detail see http://www.journals.cambridge.org.

(C) Cambridge University Press 2014. All rights reserved. No part of this publication may be reproduced, in any form or by any means, electronic, photocopy, or otherwise, without permission in writing from Cambridge University Press. For further information see http://us.cambridge.org/ information/rights/ or http://www.cambridge.org/uk/information/rights/. Photocopying information for users in the U.S.A.: The Item-Fee Code for this publication (0952-5238/13 \$25.00) indicates that copying for internal or personal use beyond that permitted by Sec. 107 or 108 of the U.S. Copyright Law is authorized for users duly registered with the Copyright Clearance Center (CCC) provided that the appropriate remittance of $\$ 25.00$ per article is paid directly to: CCC, 222 Rosewood Drive, Danvers, MA 01923. Specific written permission must be obtained for all other copying.

About the Cover. By recording light-evoked synaptic currents, Crook and coworkers explore, in the present issue, the synaptic circuitry underlying the receptive field properties of parasol cells in the macaque retina. 